\title{
Erratum to: Progress in Slag Foaming in Metallurgical Processes
}

TAI XI ZHU, MATTHEW PETER KING, K. S. COLEY, and G. A. IRONS

DOI: $10.1007 / \mathrm{s} 11663-012-9794-4$

(C) The Minerals, Metals \& Materials Society and ASM International 2013

\section{Erratum to: METALLURGICAL AND MATERIALS \\ TRANSACTIONS B, Vol. 43B, 2012, pp. 751-57 \\ DOI: $10.1007 / \mathrm{s} 11663-012-9654-2$}

THE correct listing of authors for this paper is:

Tai Xi Zhu, Matthew Peter King, K.S. Coley, and G.A. Irons

TAI XI ZHU, Ph.D. Candidate, is with the Materials Science and Engineering Department, Steel Research Centre, McMaster University, Hamilton, ON L8S 4L8, Canada. Contact e-mail: zhutx@mcmaster.ca MATTHEW PETER KING, formerly Graduate Student at McMaster University, is currently a Metallurgist with Essar Steel Algoma, Sault Ste. Marie, ON, Canada K.S. COLEY, Professor and Associate Dean Academic, is with the Faculty of Engineering, Steel Research Centre, McMaster University. G.A. IRONS, Professor and Director, is with the Steel Research Centre, McMaster University.

The online version of the original article can be found under doi: 10.1007/s11663-012-9654-2.

Article published online February 21, 2013. 